\title{
Education of Media Literacy and Ideology \& Politics
}

\author{
Huali Zhong \\ School of Journalism \& Communication, China West Normal University, Nanchong, China \\ Email: 471197046@qq.com
}

Received 19 November 2015; accepted 26 December 2015; published 29 December 2015

Copyright (C) 2015 by author and Scientific Research Publishing Inc.

This work is licensed under the Creative Commons Attribution International License (CC BY). http://creativecommons.org/licenses/by/4.0/

(c) () Op Open Access

\begin{abstract}
With the continuous development of society, media literacy education has an increasingly important position and role in university ideological and political education. Therefore, making media literacy education suit university ideological and political education is of great significance to ensure the comprehensive efficiency of ideological and political education. The concept of media literacy education, followed by its inner connection with university ideological and political education, is first introduced in this work. Then negative factors influencing the function of media literacy education in ideological and political education are analyzed. Moreover, practicable principles and measures are proposed to inspire the function of media literacy education in ideological and political education.
\end{abstract}

\section{Keywords}

Media Literacy Education, Ideological and Political Education, Relations, Current Situation, Strategies

\section{Introduction}

Continuous development of the society promotes the prosperity progress of various industries, bringing up many new things which provide their value while making requirement to people. Meanwhile, people gradually understand these new things while satisfying their requirements. Media literacy is actually a presentation of ability based on traditional literacy (Wang, 2013).

Media literacy, an extension of traditional literacy, covers people's valid interpretation of information in different media forms. It does not only include abilities of listening, speaking, reading and writing, but also advocates people to form their own criticism ability to judgments from media information. Moreover, it contains the ability to make media information by information technology. Media literacy education, aiming to form people's 
ability of reasonably controlling information, helps build people’s education concept of identifying evaluation information through effective media content.

\section{Inner Connection between Media Literacy Education and Ideological \& Political Education}

For university students, media literacy education is an effective way to improve their comprehensive ability. Media literacy education can promote students' correct judgment, rational logical ability and sharp observation, etc. (Zhu, 2013). Therefore, there is a close relation between media literacy education and university ideological and political education.

a) Media literacy education - a convenient platform for university ideological and political education

University ideological and political education requires other effective means more than verbal teaching to realize and control in most time. Otherwise, educational effect can hardly reach expectation. Media information offers university students more thinking chances through Internet, books, magazines and telecast. In this way, university ideological and political education can be smoothly advanced with the effort of various media. It is hard to imagine the effect of ideological and political education relied only on cramming teaching method. Thus, different media, as effective means, offers origins for university students. Therefore, strengthening media literacy education can tone up students' metal health, perfect their personality, rationalize their thoughts and eventually make them more mature. Consequently, media literacy education offers a convenient platform for university ideological and political education.

b) University ideological and political education-a complete goal of media literacy education

The effect of university ideological and political education will not be good without active participation of media literacy education. After all, university students cannot get more information due to limited resources and range. Thus the perfection of their thoughts and improvement of university overall ideological and political education level will be influenced. Therefore, while media offers great information for students, university ideological and political education raises necessary requirements to facilitate self-improvement of media information. In this way, media literacy education will have more development space to give full play to their value and meet the requirements of ideological and political education. Ideological and political education reacts upon media literacy education eventually, giving a helpful way of perfecting media literacy.

In conclusion, there is interplay between media literacy education and university ideological and political education, which offers a possibility for students to improve their judging ability. Meanwhile, university ideological and political education gives more higher and necessary requirements to facilitate the self-improvement of media information. Therefore, if both kinds of education play their roles, university education level can be comprehensively improved.

\section{Negative Factors Influencing Media Literacy Education}

Media literacy education is of great necessity and importance for university students while its relation with ideological and political education is very obvious. However, there are some negative factors influencing the working out of media literacy education in ideological and political education. Thus we have to learn these factors overall.

a) Backward ideas of university leaders and missing knowledge of media literacy education

Most often, university leaders are not able to change their mind with the development of social educational situation. Therefore, they still believe university ideological and political education should rely on persuasive teaching rather than other means which will be the barrier for achieving the goal of ideological and political education. The missing knowledge of media literacy education will finally influence the development of ideological and political education.

b) Ignorance of media literacy education caused by plain campus culture

Campus culture is an impulse containing some inevitable requirements for students in a sense. However, campus cultures in many universities are plain and without the participation of media literacy education. In this way, media literacy education cannot enrich campus culture without an obvious and high position. Therefore, its function to university ideological and political education is even more obscure.

c) Effected application of media literacy education caused by unreasonable study method

At present, students are used to perfecting their thoughts by reading media information to broadening their horizons. However, many students read information roughly without analyzing its deep meaning. Thus, media 
information becomes a story instead of playing its role to influence effect and level of ideological and political education.

d) Effected development of ideological and political education caused by defective media information

Media information is important to university ideological and political education, thus its objective reality is more vital. However, some media information with low reliability directly influences students' judgment and discriminability. In this way, media literacy education, still in infancy, cannot inspire students' ideological ability, which is not good to develop ideological and political education.

\section{Principle of Media Literacy Education Implementation}

Media literacy education is of great significance, thus, feasible principles are required to realize university ideological and political education through media literacy education. Good principle implementation can help media literacy education play its role in deepening university ideological and political education.

\subsection{Principle of Clear Theme}

Media literacy education generally relies on various effective information, thus this information cannot be cut off from real situation. After all, university ideological and political education cannot be realized without the basis of reality. The theme of media literacy education should center on politics, economics, culture and environment protection. Therefore, only by clearly determining the theme of media literacy education can educational work develop smoothly with correct direction, ensuring the education quality.

\subsection{Principle of Individuality}

Media literacy can be oriented to various people. Therefore, media literacy education should be equipped with individuality constantly when facing university students. Otherwise, its function will be weakened. The knowledge range of university students is wide, thus media literacy education should be carried out aiming at students' age, personality, hobby and mental quality. In this way, ideological and political education can be advanced without blind process.

\subsection{Principle of Enriching Media Information Resources}

There are large amounts of university students who dabble in different aspects. Therefore, the diversity of information should be considered in university ideological and political education. Only when information is abundant enough, can advantages of media information be shown, and can students' requirements be satisfied, thus laying a firm foundation for students to improve their judging ability. Otherwise, their ideological level will not be promoted and perfected.

\subsection{Principle of Effective Link between Different Medium Fields}

Media literacy education requires effective intermediary. However, medium fields should present various levels such as message sender, message receiver (students) and relevant system. These levels should work together to provide students with objective and effective media information. Therefore, different medium fields should be fully linked to ensure better university ideological and political education.

\section{Positive Strategy to Advance Media Literacy Education}

University quality-oriented education will be in a dilemma without media literacy education, which directly influences the effect of ideological and political education. Therefore, we should analyze current situation, adhere to our principles and take effective measures on the basis of reality, making media literacy education present its desired effect. In this way, the quality and level of university ideological and political education can be better guaranteed.

\subsection{Mind Change of University Leaders and Position Reconstruction of Media Literacy Education}

Firstly, university leaders should strengthen their learning ability, spending certain energy and time on study. 
They should clearly understand current situation of university ideological and political education, learning educational knowledge advanced with time. Thus, leaders can understand the importance of media literacy for students and the development of school knowledge. Once leaders' mind gets changed, they can offer strong guarantee for media literacy education which benefits the development of university ideological and political education.

Secondly, leaders should clearly understand the deep connection between media literacy education and ideological and political education. University ideological and political education cannot work without media literacy education and the achievement of educating and supervising students requires both media literacy education and system of ideological and political education. If student's ideological quality is not good enough, it is difficult for him to satisfy complex social requirements.

\subsection{Enrichment of University Campus Culture and Introduction of Media Literacy Education}

Firstly, campus culture is the concentrated reflection of university study, discipline and ideological level. Therefore, we should learn the importance of media literacy education to ideological and political education in building campus culture. Moreover, builders should learn functions of media literacy education. Thus it is necessary to enrich media literacy education to ideological and political education. In this way, better platforms can be offered to students to form medium quality and integrate into ideological and political education.

Secondly, students should have the chance to speak out their advice for media literacy education. In this way can campus culture be objective to ideological and political education on the basis of students' advice. Therefore, campus culture can be perfected with individuality to help the deep progress of media literacy education and ideological and political education.

\subsection{Scientific Learning Method and Deep Understanding of Media Information for Students}

Firstly, students should learn to receive media literacy education with scientific study method. Only by this way can they better integrate into ideological and political education. Therefore, students should form proper learning attitude and make reasonable understanding of media literacy education. Students should learn media information deeply instead of receiving it roughly. In this way, students can realize the perfection of their ideological world and receive ideological education positively.

Secondly, universities should open green channel to offer more media information to students. For example, universities can perfect library resources and provide more books and magazines to help students receive ideological education in the environment of media literacy education. Meanwhile, students can satisfy their study desire by modern network platform, thus they can receive media literacy education with high efficiency as well as completing ideological and political education, improving their mind through media information.

\subsection{Perfection of Media Information to Guarantee the Progress of Ideological and Political Education}

Firstly, the authenticity and objectivity of media information are of great practical significance for students to better receive media literacy education. Therefore, information should be strictly checked to ensure students get true information, which is beneficial for them to improve their ideological level. Once the information is not correct, students' judgment and discriminability will be influenced, thus affecting ideological and political education and its achievement.

Secondly, in specific, relevant medium should think about their message transmitting quality in operating mechanism, staff quality and relations between managerial supervision system and audience. In this way can media literacy education be smoothly advanced through effective information? After all, inner operation of medium is closely related to the authenticity of media information. Media literacy education can finally build an optimistic future for university ideological and political education.

\section{Conclusion}

University ideological and political education still has a long way to go. Media literacy education plays a critical 
and guiding role in improving students' ideological and political level. Therefore, it is urgent to carry out university ideological and political education through effective media literacy education. We should analyze the reason, hold the principle and solve current problems with effective measures on the basis of current situation, contributing to improvement of university ideological and political education level.

\section{References}

Wang, K. X. (2013). Media Literacy Education: New Perspective of University Ideological and Political Education. Journal of Inner Mongolia University for the Nationalities, 3, 42-42.

Zhu, H. (2013). On College Ideological and Political Work Optimization in the Background of Media Literacy Education. Journal of Juamjusi Education Institute, 2, 28-28. 